\title{
Deregulation of the Nigerian Telecommunication Sector: Interrogating the Nexus Between Imperialism and Development
}

\author{
Chidozie, Felix Chidozie (PhD)
}

Department of Political Science and International Relations, Covenant University, Ota, Ogun State, Nigeria

Email: felix.chidozie@covenantuniversity.edu.ng

\section{Lawal Promise Odunayo}

Department of Political Science and International Relations, Covenant University, Ota, Ogun State, Nigeria

Email: Odunayo.lawal@gmail.com

\section{Ajayi Olumuyiwa Olutosin}

Department of Political Science and International Relations, Covenant University, Ota, Ogun State, Nigeria

Email: muyiwa.ajayi@covenantuniversity.edu.ng

Doi:10.5901/ajis.2015.v4n1p173

\begin{abstract}
This study investigates the deregulation of the Nigerian Telecommunication Sector within the precinct of Imperialism and development. This is premised on the fact that Nigeria's Telecommunication sector has not only been moribund over the years but has more importantly been dominated by foreign and local bourgeoisies after its deregulation in 1999. In view of this, the study borrows from Structural Imperialism which argues that the elites in the Centre and Periphery states connive, indeed conspire to undermine development in the latter. It relies heavily on the use of secondary data, by virtue of the nature of the work, thus probing the dynamics of these Centre/Periphery trajectories. Findings reveal that certain levels of development have been recorded in the Telecommunication sector particularly in terms of contribution to the Nigerian economy through the ubiquitous provision of telecommunication lines, especially the mobile phones. Similarly, jobs have been created within this sector in terms of its contribution to Nigeria's GDP profile. However, beneath these efforts, the predatory and materialistic character of the foreign and local bourgeoisie, a permanent feature of the post-colonial Nigerian state remains the greatest bane of the growth of this sector. The study concludes that until this "unholy alliance" between the foreign and local bourgeoisies is demolished, the deregulation effort of the federal government will remain a mirage. To this end, it recommends an immediate measure to increase the legislative oversight of the regulatory body, Nigerian Communication Commission (NCC) over the activities of the foreign mobile operators in Nigeria, while not neglecting, indeed promoting the indigenous operators of the telecommunication services in the country.
\end{abstract}

Keywords: Imperialism, Development, Deregulation, Telecommunication Sector

\section{Introduction}

As at the time of her independence, the Nigerian state was just beginning her journey into development. To undertake this journey, the government intervened and established its presence significantly in the economy. This was prompted by the fact that government was perceived to be a driver of economic development, expected to provide infrastructure and services, provide capital that could not be afforded by the private sector which was still undeveloped to take advantage of market opportunities. As a result, government established State Owned Enterprises (SOEs) in various sectors of the economy such as petroleum, telecommunications, power, aviation, steel, media and transportation.

The management of such extensive public structure was facilitated by the oil boom of the 1970s and 1980s (Jerome, 2008). However, these SOEs proved detrimental to the economy of Nigeria, as they were characterized by poor performance due largely to gross mismanagement; were in precarious financial position with huge debts and losses. This made them heavily dependent on financial support from the government, through direct and indirect means such as grants, discounted loans and monopoly privileges. Adoga (2008) described the state of SOEs thus:

At the same time, annual profit of these corporations plummeted due primarily to corruption and inefficiency... excessive bureaucracy, defective ownership structures, gross incompetent management, complacency, defective capital 
structures, lack of effective control and supervision by the government, outdated technology, nepotism, international competition e.t.c (Adoga, 2008:10)

By mid-eighties, the international crash in oil prices, due to oil market glut resulted in reduced income for Nigeria, and the usual huge amount being pumped into these corporations could no longer be sustained by the government. The Structural Adjustment Program (SAP) designed by International Financial Organizations (IFO), specifically the World Bank and the International Monetary Fund (IMF), to help Nigeria and other African states out of the economic crises they faced was centered on the deregulation of the economies of these countries.

In effect, the deregulation of the Nigerian economy began in 1988 with the creation of the Technical Committee on Privatization and Commercialization (TCPC), to oversee the privatization program. From 1988-1993 when the program was suspended, TCPC had privatized 55 firms. Deregulation of the Nigerian economy was intended to serve as a tool of development and undoubtedly, some level of development have been recorded such as increase in profitability as most privatized companies have generated income for the government in form of taxes, better quality of goods and services provided. However, all these meet the criteria of development from an economic perspective. Other socio-economic indicators of development like inflation rate, per capita income, poverty and unemployment have not witnessed any improvement so far. More so, majority of the private companies that were allowed into the sector are Multi-national Companies (MNCs). The implication of this is that the vital sector of telecommunication in Nigeria is being dominated, indeed hijacked by foreign companies.

In other words, the means of production and labor are controlled by foreigners and a few elites. This move is akin to colonialism by the West, when the whites controlled the affairs and ruled Nigerians via traditional rulers. However, this time, it is quite subtle and engages the use of economic instruments. The most suitable term for this condition is imperialism of which Griffiths, O'Callaghan and Roach argue:

A policy aimed at conquering or controlling foreign people and territory....an imperial state....seeks to derive benefit of some sort from those states or peoples unable to defend themselves against its superior...economic force. (Griffiths, O'Callaghan and Roach 2008: 135)

The Nigerian Telecommunication sector was one of the sectors that experienced deregulation. Hitherto, the sector was made up of the Department of Posts and Telecommunications (P\&T), in charge of the internal network and a limited liability company, the Nigerian External Telecommunication Limited (NET) responsible for external telecommunication services. It metamorphosed into NITEL in 1985 and on the heels of the privatization policy of the Olusegun Obasanjo administration in 1999 other private telephone operators became key players in the industry. Consequently, by 2007, the total number of telephone lines in the country had risen from 450,000 to 38 million and 85 million by 2010, due to the introduction of mobile network, and this huge success has been accredited to the effort of privatization in the sector (ljewere and Gbandi, 2012; Okonjo-Iweala, 2012).

This success recorded in the deregulation of the telecom industry had ripple effects on the Nigerian economy, catalyzing development in other sectors of the economy such as agriculture, health, tourism and education. However, as stated earlier, these developments can be said to be superficial, satisfying only the economic criteria of development, and has become a tool of imperialism by the West, as the sector is currently dominated by foreign Multinational Companies (MNCs).

In view of this background, the study is divided into five sections. Following the introduction, key concepts are defined. The third section provides a background to the deregulation of the telecommunication sector in Nigeria. The fourth section narrows the discourse by bridging the gap between imperialism and development in the telecommunication sector in Nigeria. The last section concludes the paper.

\section{Conceptual Discourse}

The key concepts in the paper are clarified in the following section. This is necessary to avoid ambiguities and misconceptions that usually trail the use of certain concepts.

\subsection{Imperialism}

Babatola et al (2012) describes imperialism as a political and economic ideology of Western Europe in the $19^{\text {th }}$ and $20^{\text {th }}$ centuries employed to justify the economic and political activities of the western nations across their borders. Thus, the concept of imperialism is closely related to the concepts of capitalism and colonialism. In fact it can be said to be an off shoot of these concepts. The industrial revolution which heralded the capitalist economic system gave rise to increased 
production of goods, the replacement of humans with machines in the production process and the need for more raw materials, which incidentally engendered imperialism (Hussain, 2004; Salami 2009). The implication of this was that the non-industrialized countries constantly exported raw materials at cheaper rates to the industrialized countries, while they purchased from the latter manufactured goods at exorbitant prices.

However after the Second World War, Multi-National Corporations (MNCs), generally acclaimed to be the main vehicle of imperialism, particularly after the Cold War emerged, undertaking the production of goods and services in the industrialized countries. These MNCs, though they engender growth due to their large size in terms of capital, labor and infrastructure, display monopolistic tendencies, dominating whatever sector they find themselves in. The implication of this is that indigenous firms might be pushed out of the sector, and even infant industries intimidated. They are also being accused of damaging the environment, corruption, human rights abuses, over-invoicing and capital flight (Ozoigbo and Chukuezi, 2011; Osuagwu and Ezie, 2013). In other words, they are replicating what the industrialized countries did during the colonial era which is exploitation of less industrialized countries and transferring profit to their home countries, thereby developing their home countries at the expense of the host countries.

According to Sutcliffe (1999:139), imperialism is "essentially the idea that the world contains an undesirable hierarchy of nations in which some oppress or exploit others, or strive to do so". The first wave of imperialism as described by him occurred between 1890 and 1917, when force was applied in the expansionist activities of Europe as well as the struggle for domination between its major powers. The second wave views imperialism as collective domination of Third world countries by a few industrialized countries, as well as the gap between developed and underdeveloped countries. Tucker (1999:1) describes imperialism as "a process whereby the lives of some peoples, their plans, their hopes, their imaginations, are shaped by others who frequently share neither their lifestyles, nor their hopes, nor their values".

V.I Lenin illuminated the concept and philosophy of imperialism, situating it within the context of economic process. According to him:

...The relation of interdependence between two or more economies and between these and world trade assumes the form of dependence when some countries (the dominant) can expand and give impulse to their own development, while other countries (the dependent) can only develop as a reflection of this expansion. This can have positive and or negative effects on their immediate development. In all cases, the basic situation of dependence leads to a global situation in dependent countries that situates them in backwardness and under the exploitation of the dominant countries. The dominant countries have a technological, commercial, capital resources and social-political predominance over dependent countries (with predominance of some of these aspects in various historical moments). This permits them to impose conditions of exploitation and extract part of the domestically produced surplus... (Lenin, 1965)

According to Lenin, imperialism hinges the economy of a less developed country to a more developed country, such that the growth of the former is dependent on the latter. This indicates that acts such as colonialism are imperialist in nature. Kegley (2007:12) views imperialism as "international imposition of one's state power over another, traditionally through territorial conquest, but more recently through economic domination". Gartzke and Rohner (2011) argue that the end of World War 2 marked the end of the custom of territorial expansion- however; institutions and economies of the new nations are created to manage the legacies of colonial rule, which makes them highly dependent.

Economides and Wilson (2001:49) examined the concepts of 'formal and informal' imperialism. According to them, the former refers to the "acquisition of and direct control over specific territories, while the latter denotes less explicit, even covert, control, influence or domination". Informal imperialism does not tamper with the country's formal sovereignty or constitutional independence, but covers a particular sphere of influence - For instance, an economically powerful state influencing greatly, the economic policies of a weaker state.

Gillis et al (1983) view imperialism as barriers placed by advanced countries on the path of progress of poor countries. They argue that the drain of surplus from the developing countries is not the only problem, but also the misuse of the surplus in these countries. In other words, developing countries should be left to supply raw materials as "industrial growth within the developing country would be harmful to both goals, since local industry products will compete with imports and would also bid for local raw materials" (Gillis et al, 1983:32). They also recognize the presence of "commercial capitalists in the developing countries that align with foreign investors because "they make their living from existing pattern of trade and do not want competition from newer patterns" (Gillis et al, 1983:32).

The impetus for imperialism according to Karl Marx (1970) is capital accumulation via the creation of surplus value, driven by the need to profiteer. The surplus value demands a market and source of raw materials, hence the imperialist activities. 


\subsection{Development}

The concept of development is one that is widely contested and ambiguous, thus making a generally acceptable definition difficult to come by. This is because what constitutes development differ from people to people, so also the bench mark for measuring differs. Kanbur (2001:5) opines that "since development depends on values and alternative conceptions of the good life, there is no uniform or unique answer". A group of scholars referred to as post-modernists view development as "a set of ideas that shapes and frames reality and power relations, by valuing certain things over others" (Hickey and Mohan, 2003:38). This implies that valuing of economic assets over other things will make countries that do not possess economic assets to be viewed as inferior compared to those that do.

There is a technocratic perception of development that is used majorly by international development donor agencies, which focuses on what Gore (2000:794) describes as "performance assessment". It is usually tied to the achievement of short and medium-term Millennium Development Goals (MDGs). The performance of countries in terms of poverty reduction, increase in life expectancy, adult literacy and other MDG goals have become major criteria for giving assistance to developing countries by institutions such as the Organization for Economic Cooperation and Development (OECD), Development Assistance Committee (DAC) and World Bank.

The United Nations Development Decade (1960-70) described development as "... growth plus change". Change in turn is social, cultural, as well as economic; qualitative as well as quantitative....the key concept must be improved quality of people's life". There are different dimensions of development- economic, social, political, legal and institutional structures, technology, the environment, religion, arts and culture.

Bellu (2011:25) views development as an "event constituting a new stage in a changing situation". He stresses the multi-dimensional nature of development i.e it can occur in different ways, at different rates and propelled by different causes. According to him, there are various types of development, which include, among others, economic, human, sustainable and territorial developments.

For Tucker (1999), development is a western concept used to describe the process by which the West dominate other people and affect their destinies in line with their (west) perception of the world. He contends that development is part of the imperial process, where the "developed countries manage, control and even create the Third World economically, politically, sociologically and culturally". Pieterse (1999:79) advanced the concept of "Balanced Development' which he describes as a "balance between economic growth and redistribution, and between growths across different sectors". Soubbotina (2004) argues that indicators of wealth such as Gross Domestic Product (GDP), per capita income only show the quantity of resources a country has, but says nothing about the distribution of these resources. Hence, we have countries that have similar incomes but differ in terms of quality of life obtainable and this covers areas such as access to education, security, employment and others.

Todaro and Smith (2009), stress the fact that the traditional conception of development is within the framework of economic development, measured with indices such as Gross National Income (GNI) and per capita income. However, in the 1970s, development was redefined and measured against the back drop of poverty elimination, inequality and unemployment. Willis (2005:39) emphasize the fact that development is a process towards modernity that entails "a move from agricultural societies with traditional cultural practices, to a rational, industrial and service focused economy". Dutt (2001) argues that development differs from growth in the sense that the former is a broader term that covers all areas social, political, human-, and aims at purposeful improvement of society and human well-being.

\subsection{Deregulation}

Olashore (1991:115) argues that deregulation is an "economic policy and is often used synonymously with liberalization to mean the removal of official restrictions on consumer choice and the introduction or extension of competition on the supply side of market". He contends that it is a way of relying on private entrepreneurs as a motivator for development. He stress the differences between deregulation and privatization, saying while deregulation abolishes monopoly, privatization is what transfers ownership from public to private sector. In other words, privatization is an instrument under deregulation.

Dhanji and Milanovic (1999) identified the following as the purpose of deregulation: creation of a market economy, increase in economic efficiencies, establishment of democracy and guaranteeing political freedom and increasing government revenue. They argue that an economy based on the prosperity of private individuals is better and serves as a way of preserving individual freedoms than an economy where productive apparatus are socially owned.

Owojori (2011:3) views deregulation as "the process of reducing or eliminating specific governmental rules and 
regulations that applies to private business". It is the expansion of private sector activity and consequently the reduction in public sector size, in the interest of productive efficiency. One of the benefits is that it attracts foreign investment into the country. However, he warns that corrupt practices in the government circles will reduce the effectiveness of deregulation as a policy towards development.

Eme and Onwuka (2011:14) define deregulation simply as "either the partial or total withdrawal of government controls in the allocations and the production of goods and services". According to them, the benefits of deregulation are effectiveness and efficiency, foreign investments, redirecting of governments fund to other sectors and breaking the monopoly of public enterprises, ensuring greater access to consumers. They however contend that though deregulation is a desirable tool of development, it should occur in stages, so as to allow state-owned monopolies to regain efficiency, before full privatization.

Ernest and Young (1988) see deregulation as one of the various economic policy tools with the ultimate aim of improving the overall economy in well defined ways such as ensuring efficiency and effectiveness in utilization of resources, reduction of the government's debt burden, income generation for the government, and promotion of a free market that is characterized by healthy competition. They argue that, the above factors must be combined with other efforts towards development for it to perform to its maximum level in bringing about expected results. In other words, deregulation cannot work in isolation.

Bannock et al (1999:10) defines deregulation as "the process of invigorating activity in a sector of the economy by reducing the burden of government controls, particularly those that have the effect of creating barriers to entry". They argue that the major goal of deregulation is to promote competition in sectors that were once considered as natural monopolies or where regulation has outlived its intended purpose. The problem they identified with deregulation is that it forces producers into a tight competition and along the line, normal social obligations are ignored. They argue that though deregulation and privatization are intertwined, deregulation is still more important of the pair.

However, the danger of deregulation is that a few private individuals with overriding influences can dominate a sector and create an oligopoly (a market in which a few number of producers control the supply of a commodity and also influence price). These private individuals could also exploit the consumers with high prices (O' Hara, 2001). Hence the need for a regulator, that will monitor the pricing of the goods and services and also quality of goods and services provided.

Haque (1999) identifies deregulation within the context of an ideological shift on the path of states (developed and developing alike) from a state-centered interventionist perspective to a market-driven perspective. In respect to developing countries, the reason for adopting state-centered policies in the first place was to reduce foreign ownership as they were just being freed from colonialism, promote economic self reliance, develop infrastructure, redistribute income and generally, improve the standard of living of people.

However, shortly after this transition from colonialism to political freedom, the economic objectives headed towards a different direction which includes: stabilization, productivity, competitiveness, attraction of foreign investment and efficiency. This led to the adoption of market-oriented principles such as deregulation, privatization and liberalization. Haque however considers these polices as a threat to the achievement of sustainable development which he defines as "improvement of current living standards without jeopardizing future living conditions" (Haque, 1999:8).

\section{Backgrounds to the Deregulation of the Nigerian Telecommunication Sector}

The first telecommunication facility in Nigeria was a cable connection between the colonial office in London and Lagos established by the colonial administration in 1886. Telephone services were later made available to government offices in 1893, and later extended to the hinter land such as Ilorin and Jebba. The first commercial trunk telephone service between Calabar and Itu was established in 1923; a steady development of telecommunication in the country thus began. A three-channel line carrier system between Lagos and Ibadan was commissioned and later extended to Benin, Enugu, Kano, Kaduna, Kano and Osogbo; this took place from1946-1952 (Ajayi et al, 1999).

The equipments used were changed- small to medium capacity systems that employ the use of VHF and UHF radios were introduced, and also the use of Strowger exchanges as against manual pegboards. These telecom infrastructures were put in place by the colonial masters and they were intended to help in administrative functions and not mainly for socio-economic development of the country (Ajayi et al, 1999).

At independence in 1960, there were only 18,724 phone lines available to a population of about 40 million (ljewere and Gbandi, 2012) and this was grossly insufficient. In the face of this reality, four national development plans were executed towards the improvement of the current state of the network and infrastructure, and they were supervised by the 
Ministry of Communications. Some of the intended objectives were: installation of additional telephone lines, expansion of trunk dialing facilities to link the major urban centers, and the establishment of an institution in the sector Nigerian External Telecommunications (NET) Limited (Ajayi et al, 1999).

These objectives were not totally achieved, but some level of improvements were recorded such as, the connection of major cities via microwave radio transmission system, the establishment of NET, increase in the number of lines in the telephone network from 52,000 to 241,000 lines, building of satellites that boosted external coverage, a microwave link connecting Nigeria and Benin Republic, and installation of an International Telephone Switching Center (ITSC). There were certain factors that limited the development of the telecom sector at this period such as inadequate funds, poor coordination of projects, interruptions such as the civil war of 1967-1970, and insufficient skilled labor force to manage the additional equipments.

Up until 1985, the institutions in the telecommunication sector were the Department of Posts and Telecommunications (P\&T) which was responsible for the internal network; and the Nigerian External Telecommunication (NET) Limited, which was a Limited Liability Company responsible for the external network. In 1985, the Posts and Telecommunications Department was separated into the Postal and Telecommunications sections, and the telecommunications sector was merged with NET to form Nigerian Telecommunications Limited (NITEL), which also became a Limited Liability Company. NITEL was established to supply to the Nigerian state efficient telecommunication services, and this required sufficient resources - financial and technical, as well effective planning and co-ordination, as it was to merge the responsibilities of planning and coordinating internal and external telecommunications, and ensure these services were affordable and accessible (ljewere and Gbandi, 2012).

NITEL was able to provide $60 \%$ of the N12 billion that was invested in the provision of certain infrastructures such as digital exchanges and transmission links, from internally generated revenues. This was a big credit to the institution. The institution also engaged in Research and Development (RD) to develop system components that suit the environment, develop solutions to technical problems and introduce new services. In 1993, NITEL introduced the voice mail, the paging system, trunked radio and phone card. The Integrated Services Digital Network (ISDN) ensured the availability of services such as electronic mail, video telephone, telefax and many more. NITEL was also able to provide telecommunication services to local governments in the country (Odukoya, 2007).

However, NITEL was faced with problems of corruption, mismanagement, inefficiency in service delivery in terms of quality; the telephone system was congested, erratic, non-customer friendly and expensive. The immediate result of these was the public outcry for state intervention to remedy the epileptic telephony services of NITEL.

Consequently, the Decree of 1992 led to the establishment of the regulatory body in the sector- Nigerian Communication Commission (NCC) as part of state reaction to the challenges of NITEL. The NCC commenced operation in 1993 with the inauguration of the first commission, however full deregulation began in 2000. The NCC was charged with the responsibility of monitoring the evolution of competition in the sector, preventing hostility against new entrants by those already existing in the market, and protection of the public against the manipulation of the market by the firms via practices such as inflated prices, reduced quality and quantity of services provided (Sodiq et al, 2011).

The NCC is also in charge of licensing telecommunications operators, engendering of private sector participation and investment, tariff regulation, interconnection disputes, supervision of technical and operational standards and practices for network, and other matters affecting the industry; and it is meant to perform these functions without bias and with all sense of autonomy, on the basis of transparency, equity and fairness. The NCC granted licenses to three GSM service providers in 1999- Econet, MTN and MTel, a Second National Operator in 2002, which is Globacom, and another operator in 2008, Etisalat. In 2006, the Universal Access Service licenses were issued to provide fixed telephony, VSAT and internet services (Alabi, 1996).

The rationale behind the deregulation of the telecommunication sector include: the inability of the government to support the sector with subsidy; the need to reduce the burden on the government, the demand for efficient and current facilities, low rate of infrastructure growth, low access especially in the rural areas, and poor service delivery.

The commercialization of the operations of the state enterprise in the late 1980's marked the beginning of the deregulation process. However, with the announcement of the National Communication Commission (NCC) Decree of 1992, telecom was divided into 2, with a part left in the hands of NITEL exclusively, while the other sector was opened to private sector participation. NITEL thus kept her monopoly over areas such as Exchange and Trunks and International Services. Section 10(a) of the Decree made provision for only Nigerians to participate in the sector, but this was amended in 1998 spelling out the criteria for being licensed.

In 1999, the then President of Nigeria, Olusegun Obasanjo made it a priority to privatize the sector totally, involving the Global System of Mobile Communications (GSM) service providers. Some private companies received licenses, but 
no operation took place until 2001 when three operators got digital mobile licenses auctioned by the NCC; the operators include Econet, MTN and MTEL. After this, there was a great explosion in the sector; by 2007 the number of telephone lines in the country grew to 38 million as against 450,000 that was in place as at 1999, and 85 million by April 2010, due largely to the mobile network, which made the country the world's fastest growing teledensity (Okonjo-Iweala, 2012).

The Telecommunication Act of 2003 encouraged more entry into the sector, engendering competition, and strengthened the role of the NCC. This paved way for the entry of the Second National Carrier which was GLOBACOM, and this has increased the intensity of competition in the sector, as each company introduces competitive and innovative packages, in order to gain the greater share of the market. As at 2004, the following had been achieved in the sector: a teledensity of $3.9 \%$ as against $0.4 \%$ at 2001 ; average of $45 \%$ of the population in an area of about $156,200 \mathrm{~km}^{2}, 3.8$ mobile lines connected in less than 3 years; 4 licensed service providers, including two National Operators; increased access to mobile phones by the people; reduction in acquisition costs of new lines; reduction in cost of internet access; employment generation on the path of the companies and the "umbrella people" (Ndukwe, 2005).

Today, the industry has gone past telephony as there are quite a number of mobile service providers such as MTN, Airtel, Globacom, Etisalat which provide a range of services that include internet, Small Messaging Services (SMS), multimedia services, internet access and mobile banking. With such development, new challenges are also arising such as ensuring conformity to best quality of service delivery; upgrading of infrastructures to meet international standard; security and maintenance of facilities, especially in the remote areas; ensuring the framework of broadband that can be accommodated by the ecosystem; and security of data in this digital world.

\section{Deregulation of the Nigerian Telecommunication Sector: Imperialism or Development?}

No doubt, ample telecommunications infrastructure is essential for a modern nation to develop to its maximum potential. Most developed countries have deregulated their telecommunication sector and it has given room for foreign investment, resulting in a developed private sector, more employment opportunities, better education and training facilities (Oshotimehin et al, 2007).

Indeed, since the entry of private sector participants into the Nigerian Telecommunication sector, there has been a record of high level of development, particularly in respect to the Nigerian economy. Deregulation in the telecommunication sector has resulted in improved infrastructure as a result of foreign investments, enhanced communication among the people, simplified business processes and transactions, employment opportunities, enhanced productivity in other sectors and increased national output (Awoleye et al, 2012).

According to statistics released by the Nigerian Communication Commission (NCC), the telecommunications sector has increasingly contributed greatly to the Gross Domestic Product (GDP) of Nigeria from $0.62 \%$ in 2001 to $8.53 \%$ in 2013; teledensity has also greatly improved from 1.89 in 2002 to 91.15 in 2013; and the subscriber base from 2,217,050 in 2002 to 127,606,629 in 2013 (NCC, 2014).

Tab. 1 - Percentage Contribution of Telecoms to GDP 2001- March 2013. Source: NCC (2014)

\begin{tabular}{|c|c|}
\hline Year & Percentage \\
\hline 2001 & 0.62 \\
\hline 2002 & 0.85 \\
\hline 2003 & 1.06 \\
\hline 2004 & 1.27 \\
\hline 2005 & 1.53 \\
\hline 2006 & 1.91 \\
\hline 2007 & 2.31 \\
\hline 2008 & 2.92 \\
\hline 2009 & 3.66 \\
\hline 2010 & 4.56 \\
\hline 2011 & 5.67 \\
\hline 2012 & 7.05 \\
\hline 2013 & 8.53 \\
\hline
\end{tabular}


Tab. 2 - Subscriber/Teledensity Data 2002-December, 2013. Source: NCC (2014)

\begin{tabular}{|c|c|c|}
\hline Year & Number of Subscribers & Teledensity \\
\hline 2002 & $2,271,050$ & 1.89 \\
\hline 2003 & $4,021,945$ & 3.35 \\
\hline 2004 & $10,201,728$ & 8.5 \\
\hline 2005 & $19,519,154$ & 16.27 \\
\hline 2006 & $33,858,022$ & 24.18 \\
\hline 2007 & $41,975,275$ & 29.98 \\
\hline 2008 & $64,296,117$ & 45.93 \\
\hline 2009 & $74,518,264$ & 52.23 \\
\hline 2010 & $88,348,026$ & 63.11 \\
\hline 2011 & $95,886,714$ & 68.49 \\
\hline 2012 & $113,195,951$ & 80.85 \\
\hline 2013 & $127,606,629$ & 91.15 \\
\hline
\end{tabular}

A breakdown of the contribution of the telecommunication sector reveals that close to N400 billion has been paid in taxes as at 2012, with network operators paying about N160 billion in taxes annually and N55 billion as regulatory levies (Ogunsanya, 2013). Since 2001, about N640 million has been paid in licenses and spectrum fees; other forms of contribution comes in payment of wages and benefits to employees, payments to contractors and Corporate Social Responsibility (CSR) programmes. The telecommunication sector has led to the development of an ecosystem that involves a lot of members ranging from contractors to base member stations deployments and system integrators, to resellers of devices, and all these members arguably benefit from the activities in the telecommunication sector (Adeyanju, 2012; Ogunsanya, 2013).

The impact of deregulation of the telecom sector in job creation is a major contribution the economy. As at 2010, the sector had created 5,000 jobs directly, and more than 400,000 indirectly (Nigerian Bureau of Statistics, 2010). According to a report in Nigerian Tribune Newspaper of July 16, 2004, government had received revenue in form of taxes and levies amounting to over N200 billion (Ajiboye et al, 2007).

The advent of Global System for Mobile communication (GSM) in Nigeria was another benefit of deregulation in the sector and it has impacted other sectors of the country's economy; for instance service sectors such as banking, education and health have had their operations made easy with ICT enabled products from the telecom sector such as mobile banking, e-payment, distance learning and e-health (Ndukwe, 2005).

Another area of development brought about by deregulation is in the area of infrastructure. In the course of their operations, MNCs have contributed immensely to the development of infrastructure in Nigeria, investing large sums of money into network roll outs, upgrades and expansion at various parts of the country. The operators have built backup networks to improve their services and such includes the construction of a core network, a transmission network and a power supply network (NCC, 2014).

For instance, MTN which has the largest infrastructure in the sector has invested a total of $\$ 7 b i l l i o n$ dollars in fixed assets and facilities nationwide. Few years after her entry into the country, MTN invested \$120 million in establishing digital microwave backbone that currently spans to Cameroun via Cross rivers state, and Niger via Sokoto state (MTN, 2014). MTN has the longest and one of the most modern privately- owned fibre- optic cable in Africa, and 10,137 kilometers of it runs through Nigeria (MTN, 2014).

Since her acquisition of Zain in 2010, heralding her entry into Nigeria, Airtel has invested \$ 1.5 billion in infrastructures and she is still investing (Ogunsanya, 2013). Globacom recently embarked on a network upgrade that involves building new switches and switching centers to ease congestion, construction of additional $4,000 \mathrm{~km}$ of optic fibre cable, installation of new base stations and densification of existing ones, and improving customer service by setting up three new mini call centers (Punch, 2013). All these efforts have helped the development of technological infrastructure and also contributed to the economy financially.

Deregulation has also led to the spread of telephone services, as against its concentration in urban areas, to rural areas, there by bridging the gap in the social, economic and political interactions between residents in the urban and rural areas. In other words, the inequality resulting from the urban-rural divide is lessened, which has implications for economic development of the country (ljewere and Gbandi, 2012).

It must be emphasized that, the essence of deregulation in the Nigerian telecommunication sector was to break the monopoly of Nigeria Telecommunication Limited (NITEL) by allowing private sector participation in the sector to 
encourage competition (Hassan, 2011). Since the Nigerian Communication Commission (NCC) issued licenses to certain private operators in 2001, the Nigerian telecommunication sector has been dominated by private participants.

Truly, what is observable is the dominance of the sector by Multinational Corporations (MNCs) among the private participants, with very few indigenous participants. There are currently 5 mobile operators in Nigeria- MTN from South Africa, Bharti Airtel from India, Etisalat from United Arab Emirates, Globacom and MTel which are indigenous with MTel being the mobile arm of the Nigerian Telecommunication (NITEL). According to the statistics released by the Nigerian Communication Commission (NCC, 2014), the communication market is dominated by MTN 56,766,085 subscribers giving it $45 \%$ of the market. It is followed by Globacom with $25,933,867$ subscribers' equivalent of $21 \%$ of the market; Airtel with $24,847,567$ subscribers, a total of $20 \%$ of the market; Etisalat with $17,035,276$ subscribers, a total of $14 \%$ of the market and MTel with 258,520 subscribers, an equivalent of $0 \%$ of the market.

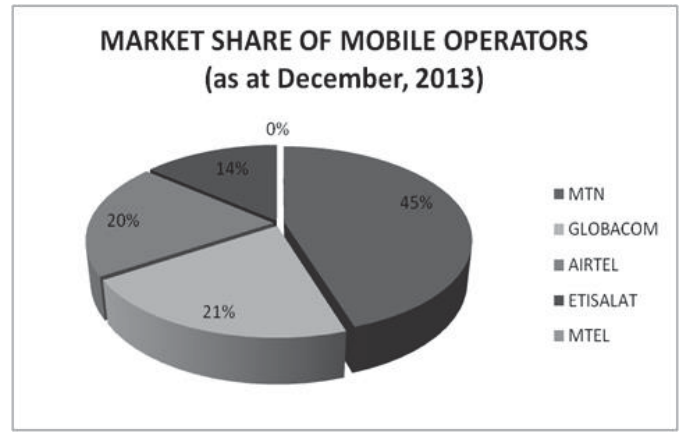

Fig. 1- Market Share of Mobile Operators. Source: NCC (2014)

\begin{tabular}{|c|c|}
\hline MOBILE OPERATOR & MARKET SHARE \\
\hline MTN & $56,766,085(45 \%)$ \\
\hline GLOBACOM & $25,933,867(21 \%)$ \\
\hline AIRTEL & $24,847,567(20 \%)$ \\
\hline ETISALAT & $17,035,276(14 \%)$ \\
\hline MTEL & $258,520(0 \%)$ \\
\hline
\end{tabular}

From the above data, we observe that there are only two national operators- Globacom and MTel- and only Globacom happens to be functioning. Even at that, the gap between the market share of MTN (which is a foreign MNC) and that of Globacom is a very wide one. It can thus be adequately argued that the Nigerian Telecommunication sector is dominated by foreign MNCs.

Similarly, the composition of the leadership of the MNCs in the telecommunication industry in Nigeria is telling enough. MTN Nigeria's key Executives are: Michael Ikpoki who is the Chief Executive Officer, Brett Goschen -the Group Chief Financial Officer, Afam Dozie- Chief Marketing and Strategy Officer, and Amina Oyagbola- Human Resources Executive. Other members include Dr. Pascal Dozie of African Capital Alliance; M. Sani Bello (OON) of Law Union and Rock Insurance; Dr. Matamela Cyril Ramaphosa of The Shanduka Group Pty Ltd.; Mr. Karel Pienaar (MTN Group); and Mr. Gbenga Oyebode (MFR) of Access Bank plc (Bloomberg Business Week, 2014).

An assessment of this composition will reveal that though there is a fair percentage of indigenous membership of this board with only three foreign members out of nine, many of them belong to the elite class of the country and can be categorized as part of the elites of the society. Mr. Michael Ikpoki who happens to be the first local CEO of MTN Nigeria was formerly the CEO of MTN Ghana and was previously working with NCC until he joined MTN in 2001. He has a degree in General Management from, Harvard Business School (Opara, 2013). Mr. Afam Dozie has spent a total of 23 years working with MNCS- Virgin, Procter \& Gamble and Motorola in Europe (Bloomberg Business Week, 2014).

Dr. Pascal Dozie having spent most of his early years and career abroad, returned to Nigeria in 1972 and has since then occupied positions of influence at various times and in different sectors in Nigeria. He was a member of the Pius Okigbo panel in 1994, a member of the Board of Directors Central Bank of Nigeria (CBN), a past president of the Nigerian Stock Exchange and still serves a member of the Exchange Council. He currently serves as a member of the Governing Council of the Nigerian Investment Promotion Commission (Commonwealth Business Council (CBC), 2014).

Board members of Airtel Nigeria include: Dr. Oba Otudeko- Chairman; Segun Ogunsanya -Chief Executive Officer 
appointed in 2012; Ross Masterman- Chief Financial Officer, Khaled Khorshid- Chief Operating Officer, Shamel Mohammed Hanafi- Chief Commercial Officer; Emeka Oparah- Head of Public Relations; and Gamaliel Oforitsenere Onosode. The board members of Etisalat Nigeria include: Mr. Stevens Evans- Chief Executive Officer; Mr. Gilles KuntzChief Technology Officer, Mr. Hakeem Bello-Osagie, and Mr. Alhaji Garba Bello (Bloomberg Business Week, 2014).

Dr. Oba Otudeko is one of the business elites in the country; he is the head of the Honeywell Group and FBN Holdings plc; he has once been the head of First Bank of Nigeria PIC and FBN Bank (UK), the 16th president and Chairman of Council of the Nigerian Stock Exchange, he has served on the board of Central Bank of Nigeria and other blue-chip companies such as Guinness Nigeria PIc and Ecobank Transnational Incorporated (Honeywell Group, 2014).

Mr. Segun Ogunsanya has served as MD of Nairobi Bottlers, Ecobank Transnational Inc., Nigerian Bottling Company and Coca-Cola Nigeria. Mr. Hakeem Bello-Osagie has an elite family background whose father has a flourishing relationship with past Nigerian Heads of state; he is an Harvard trained petroleum economist; he has been in the cabinet serving as adviser to the President on petroleum and energy, and also in the Nigerian National Petroleum Corporation (Forbes, 2014).

All these point to the fact that while these MNCs employ average Nigerians as part of the labour force, the indigenous members of the board are business or bureaucratic elites, who arguably may not represent the interest of the average Nigerians in the board. This validates the claim that imperialism involves the local and metropolitan bourgeoisies working in concert at the expense of the masses.

Finally, in the wake of deregulation, not only is the telecom market being dominated, but local productive capacity and efforts have been choked out by competition from the MNCs. Considering the fact that the industry is capital intensive, all parts of the sector ranging from mobile phones and accessories to chips, to servers and soft wares are dominated by the MNCs. The sections of the industry with local capacity input include distribution, sales and the staffs of the MNCS (Omoweh, 2002; Osemene, 2012).

\section{Summary, Recommendations and Conclusion}

The thesis attempted to juxtapose the development and imperialism debates within the pragmatics of the deregulation policies of the Federal Government of Nigeria (FGN) in the Telecommunication sector. It intended to unearth the contradictions that have trailed these debates since the full deregulation of this sector in 2001, involving the entry of the Foreign Mobile Operators into the sector. The data provided revealed that the deregulation of the Nigerian Telecommunication sector has resulted in a considerably visible level of development in the country, crisscrossing into other key sectors of the economy. However, beneath these are evidences of imperialism manifesting in various ways, due largely to the monopoly in the sector enjoyed by the local and metropolitan elites. The study recommends among others, the urgent need to institutionalize the localization of the technology that drive the operations of these Foreign Service providers to reduce over dependence on the MNCs. It concludes that, the development witnessed thus far in the telecommunication industry may not graduate into actual growth for the Nigerian economy - an issue that will continually dominate research in the nearest future.

\section{References}

Adeyanju, O. D. (2012). "An Assessment of the Impact of Corporate Social Responsibility on Nigerian Society: The Examples of Banking and Communication Industries" Universal Journal of Marketing and Business Research Volume 1, Number 1 pp: 17-43.

Adoga, O. (2008). Critical Appraisal of Privatization in Nigeria. Retrieved on 27th November 2013 from www.hr.org/articleasp?id5491.

Ahmed, A. (1993). Forward to Central Bank of Nigeria: Perspectives of Economic Policy Reforms in Nigeria. Ikeja: Page Publishers Services Ltd.

Ajayi, G. O., R. I Salawu, and T. I Raji (1999). "A Century of Telecommunications in Nigeria- What Next?" in Noam, Eli (ed) Telecommunications in Africa. United Kingdom: Oxford University Press pp: 163-179.

Ajiboye, J. O., E. O. Adu, and J. I. Wojuade (2007). "Stakeholders Perceptions of the Impact of GSM on Nigeria Rural Economy: Implication for an Emerging Communication Industry" Journal of Information Technology Impact Volume 7, Number 2 pp: 131144.

Alabi, G. A. (1996). "Telecommunications in Nigeria" a lecture delivered at the University of Pennsylvania African Centre, March 27

Awoleye, O. M., O. A Okogun, B. A. Ojuloge, M. K. Atoyebi, B. F Ojo (2012). "Socio-Economic of Telecommunication Growth in Nigeria in Nigeria: An Exploratory Study" Interdisciplinary Journal of Contemporary Research in Business Volume 4 Number 2 pp. 256 262

Babatola, J. A., J. B., Odukoya, and S., Abdulwaheed (2012). "Eurocentric Views of Africa and European Imperialism" Arabian Journal of Business and Management Review Volume 2 Number 3 pp: 1-10. 
Bannock, Graham, R. E. Baxter, and Evan Davis (1999). The Penguin Dictionary of Economics. London: Penguin Group.

Bellu, L. G. (2011). "Development and Development Paradigms: A (Reasoned) Review of Prevailing Visions" EASYPol retrieved on $2^{\text {nd }}$ of January available at www.fao.org/easypol .

Bloomsberg Business Week, (2014). "Company Overview of Bharti Airtel" retrieved on the $20^{\text {th }}$ of March available at www.investing.businessweek.com/research/stocks/private/board.asp?privcapld=9496846.

Bloomsberg Business Week, (2014). "Company Overview of MTN Nigeria" retrieved on the 20th of March available at www.investing.businessweek.com/research/stocks/private/board.asp?privcapld=9496846.

Bloomsberg Business Week, (2014). "Executive Profile- Afam Dozie" retrieved on the 20th of March, available at www.investing.businessweek.com/research/stocks/private/board.asp?persons.asp?personld=2367949.

Commonwealth Business Council, (2014). "Dr. Pascal Dozie" retrieved on 20 2 th March available at www.cbcglobal.org/about/board-ofdirectors/dr-pascal-dozie.

Dhanji, F. and B. Milanovic (1991). "Privatization in Eastern and Central Europe: Objectives, Constraints and Models of Divestiture" A World Bank Research Working Paper No. 770.

Dutt, A. K (2001). "Development Political Economy: Major Contemporary Themes" in O'Hara, Philip (ed.) Encyclopaedia of Political Economy Volume I New York: Routledge.

Economides, Spyros and Peter, Wilson (2001). The Economic Factor in International Relations- A Brief Introduction. New York: I. B. Tauris \& Co Ltd.

Eme, O. I and C. C. Onwuka (2011). "Political Economy of Deregulation Policy in Nigeria: The Challenges Ahead" Journal of Business and Organizational Development Volume 2 Number 1 pp.1-21.

Ernest, P. and C. Young (1988). The Colonial State and Post Colonial Crisis', The Transfers of Power, 1960-1980. New Haven and London: Tale University Press.

Etisalat, (2014). "Etisalat Press Release" retrieved on 20 th March available at www.etisalat.com.ng/press.php?sb_do= showfull\&id=1360743704\&archive=\&startfrom=\&us_ct.

Forbes, (2014). "Hakeem Bello-Osagie" retrieved on 21st Marc available at www.forbes.com/profile/hakeem-bello-osagie.

Gartzke, Erik and Dominic Rohner (2011). "The Political Economy of Imperialism, Decolonization and Development" British Journal of Political Science Volume 10 Number 7 pp: 1-32.

Gillis, M., D., Perkins, M., Roemer and D., Snodgrass (1983). Economics of Development New York: W.W. Norton \& Company.

Gore, C. (2000). "The Rise and Fall of the Washington Consensus as a Paradigm for Developing Countries" World Development, Vol. 28, No. 5, pp: 789-804.

Griffiths, M.; T. O'Callaghan and S.C Roach (2008). International Relations- The Key Concept. England: Routledge.

Haque, Shamsul (1999). "The Fate of Sustainable Development under Neo-Liberal Regimes in Developing Countries" International Political Science Review Volume 20 Number 2 pp 197-218.

Hassan, A. O. (2011). "Telecommunications Reform and Effects of Competition on Availability, Quality and Cost of Services in Nigeria" Public Policy and Administration Research Volume 1, Number 3 pp: 8-19.

Heather, Ken (2004). Economics Theory in Action. England: Pearson Education Limited.

Hickey, S. and Mohan, G. (2003) "Relocating Participation within a Radical Politics of Development: Citizenship and Critical Modernism" Draft working paper prepared for Conference on Participation: From Tyranny to Transformation? Exploring New Approaches to Participation in Development', 27-28 February 2003, University of Manchester, Manchester.

Honeywell Group, (2014). "Dr. Oba Otudeko CFR" retrieved on 21st March available at www.honeywellgoup.com/content.php?sid=32. Hussain, Akmal (2004). "Imperialism" in Hussain, Syed (ed) Encyclopaedia of Capitalism Volume II H-R New York: Facts on File Inc. Ihonvbere, J. (2013). "Leadership and the Future of Nigeria" in The Punch March 19 p: 9.

ljewere, A.A. and E.C., Gbandi (2012). "Telecommunications Reform in Nigeria: The Marketing Challenges" JORIND Volume 10, Number 2, pp.193-198.

Jerome, A. (2008). "Privatization and Enterprise Performance in Nigeria: Case Study of Some Privatized Enterprises" AERC Research Paper Nairobi: African Economic Research Consortium.

Kanbur, R. (2001). "Economic Policy, Distribution and Poverty: The Nature of Disagreements" World Development, Vol. 29, No. 6, pp: 1083-1094.

Kegley, C. W (2007). World Politics- Trends and Transformations Belmont: Thomson Wadsworth.

Lenin, V.I (1965). Imperialism: The Highest Stage of Capitalism Moscow: Foreign Language Press.

Marx, Karl (1970). A Contribution to the Critique of Political Economy Moscow: Round Ville Ltd.

MTN, (2014). "Corporate Information about MTN Nigeria" retrieved on $22^{\text {nd }}$ of March available at www.mtnonline.com/about$\mathrm{mtn} /$ corporate-information.

Ndukwe, Ernest (2005). "Telecom Liberalization in Nigeria: Opening Up The Market and Sector Reform" paper presented at SATCOM.

Nigeria Bureau of Statistics (2014). "2010 Review of the Nigerian Economy" retrieved on 21 st of March available at www.nigerianstat. gov.ng/pages/NBSeLibrary.

Nigeria Bureau of Statistics (2014). "2010 Review of the Nigerian Economy" retrieved on 21st of March available at www.nigerianstat. gov.ng/pages/NBSeLibrary.

Nigerian Communication Commission, (2014). Percentage Contribution of Telecoms to GDP 2001- March 2013 retrieved on the 14th March 2014 available at www.ncc.gov.ng/index.php?option=com_content\&view=article\&id=68\&ltemid=70

Nigerian Communication Commission, (2014). Performance Key Indicators retrieved on the 14th of March, available at www.ncc.gov.ng. 
index.php?option=com.contentandview=articleandid=332.key-performance-indicatorandcatid=76:cat-standardsqosanditemid=104

Nigerian Communication Commission, (2014). Teledensity Data retrieved on the 14 $4^{\text {th }}$ March, 2014 available at www.ncc.gov.ng lindexphp?option=com_contentandview=articleandid=68statistics - industryandcatid=65:cat-web-statisticsitmid $=70$

O'Hara, P. A. (2001). Encyclopaedia of Political Economy. London: Routledge.

Odukoya, A. D. (2007). "Theoretical and Empirical Issues in Privatization: A Comparative Study of the British and Nigerian Experience" Journal of Social Science Volume 14 Number 1 pp: 25-43.

Ogunsanya, Segun (2013). "How Airtel Became Nigeria's Leading Telecoms Company" in Top Celebrities April 13, retrieved on 22nd of March 2014 available at www.topcelebritiesng.com/how-airtel-became-nigerias-leading-telecoms-company-segun-ognsanya.

Okonjo-Iweala, N. (2005). "Global Economic Governance Programme" Lecture delivered at the Department of Politics and International Relations at the Oxford University College, Oxford.

Okonjo-Iweala, Ngozi (2012) Reforming the Unreformable: Lessons from Nigeria London: The MIT Press.

Okonjo-Iweala, Ngozi (2012). "Promoting Privatization, Deregulation and Liberalization" Vanguard retrieved on the $27^{\text {th }}$ of November, 2013 from www.vanguard.com/2012/promoting-privatization-deregulation-and-liberalization-by-dr-ngozi-okonjo-iweala.

Olashore, O. (1999). The Challenges of Nigeria and Economic Reforms Ibadan: Fountain Publishers.

Omoweh, Daniel (2002). "Economic Diplomacy in the Post-Adjustment Nigerian Economy: A Post- Script" in Ogwu, U. J and O. A.Olukoshi (eds.) The Economic Diplomacy of the Nigerian State Lagos: Nigerian Institute of International Affairs.

Osemene, O. F. (2012). "Corporate Social Responsibility Practices in Mobile Telecommunications Industry in Nigeria" European Journal of Business and Management Volume4 Number 8 pp: 149-159.

Oshotimehin K. O., E.Y. Akinkoye, O. O. Olasanmi (2007). "The Effects of Investment in Telecommunication Infrastructure on Economic Growth in Nigeria" paper presented at Oxford Business and Economics Conference, St. Hugh's College, Oxford University June 28-29.

Osuagwu, Godwin and Obumneke, Ezie (2013). "Multinational Corporations and the Nigerian Economy" International Journal of Academic Research in Business and Social Sciences Volume 3 Number 4 pp: 359-369.

Owojori, A. A. (2011). "The Effect of the Emerging Economic Policies in Investment in Nigeria" Journal of Emerging Trends in Economics and Management Sciences Volume 2 Number 3 pp. 206-214.

Ozoigbo, B., and Chukuezi, C. (2011). "The Impact of Multinational Corporations on the Nigerian Economy" European Journal Of Social Sciences Volume 19, Number 3 pp.9-20.

Pieterse, J. N (1999). "Critical Holism and the Tao of Development" in Ronaldo, Munck and Dennis, O' Hearn (eds.) Critical Development Theory- contributions to a New Paradigm New York: Zed Books.

Salami, Y. K (2009). "The Political Economy of Nigeria and the Continuing Agenda of Recolonization: A Challenge for Critical Knowledge Production" Journal of Pam African Studies Volume 3 Number 3 pp: 131-141.

Sodiq, O. M., A.O Oyelade, C. A. Ukchuwu (2011). "10 Years of Telecommunication Infrastructure Development in Nigeria" a paper presented at the International Conference on Innovations in Engineering and Technology August $8^{\text {th }}-10$ th

Soubbotina, Tatyana (2004). Beyond Economic Growth- An Introduction to Sustainable Development World Bank Publications.

Sutcliffe, Bob (1999). "The Place of Development in Theories of Imperialism and Globalization" in Ronaldo, Munck and Dennis O' Hearn (eds.) Critical Development Theory- contributions to a New Paradigm New York: Zed Books.

Todaro, M. P. and S.C. Smith (2009). Economic Development Cambridge: Pearson.

Tucker, Vincent (1999). "The Myth of Development: A Critique of a Eurocentric Discourse" in Ronaldo, Munck and Dennis O' Hearn (eds.) Critical Development Theory- contributions to a New Paradigm New York: Zed Books

Tucker, Vincent (1999). "The Myth of Development: A Critique of a Eurocentric Discourse" in Ronaldo, Munck and Dennis O' Hearn (eds.) Critical Development Theory- contributions to a New Paradigm New York: Zed Books.

United Nations, (1962). The UN Development Decade: Proposals for Action New York: United Nations.

Willis, Katie (2005). Theories and Practices of Development. New York: Routledge. 